i zasukhoustojchivosti plodovyh rastenii. Kishinev: Shtiinica. 80 p. (in Russian).

Lishchuk, A. I. (1980). Opredelenie vodouderzhivajushchej sposobnosti i stojkosti k obezvozhivaniju list'ev i pobegov / Programma i metodika selekcii plodovyh, jagodnyh i orekhoplodnyh kul'tur. Michurinsk,. S. 473-476. (in Russian).

Oksantiuk, V. M. (2018). Rid Cotinus Mill. u Pravoberezhnomu Lisostepu Ukrainy (biologiia, ekologiia, introdukciia, vikoristannia): monografiia. Kyiv: PALYVODA A. V., 144 p. (in Ukrainian).

Pjatnickij, S. S. (1961). Praktikum po lesnoj selekcii. Moskva: Sel'hozizdat. 27. (in Russian).

УДК 58.036.2:58.036.5

\title{
Порівняльний аналіз зимо- та посухостійкості різновікових рослин виду Cladrastis kentukea (Dum.-Cours.) Rudd в умовах Національного дендрологічного парку «Софіївка» НАН України
}

\author{
Ольга Л. Порохнява \\ Національний дендрологічний парк «Софіївка» НАН України, м. Умань, Україна; e-mail: porokhniava@gmail.com \\ ORCID ID0000-0002-9636-9990
}

\section{Реферат.}

Meта. Роботу присвячено дослідженню зміни ступеня зимо- та посухостійкості у різновікових особин виду C. kentukea. Отримані результати дають змогу виявити, в якому онтогенетичному стані рослини найстійкіші до несприятливих умов навколишнього середовища. Методи. Періодизаџію онтогенезу C. kentukea виконано за класифікаџією вікових станів рослин Т. О. Работнова (1950) з доповненнями О.О. Уранова (1975) і його учнів. Посухостійкість визначено візуальним методом за 6-бальною шкалою С. С. П'ятниџького (1961). Візуальну оџінку зимостійкості виконано за 8-бальною шкалою С. Я. Соколова (1957), коефіџієнт зимостійкості визначено за методикою I. С. Косенка (2002). Результати. У період посухи спостерігали часткове пошкодження рослин C. kentukea у різних онтогенетичних станах, шо вплинуло на бал оџінки фактичної посухостійкості. Ювенільні рослини виявились найбільш чутливими до дії посухи, у деяких з них було зафіксовано локальні пошкодження країв листкових пластинок та втрату тургору. Рослини у генеративному стані в џілому не пошкоджувались дією посухи, лише інколи на окремих пагонах спостерігали опіки країв листкових пластинок у особливо посушливий період. Виявлено, шо чим більша різниџя між тривалістю росту пагонів і середньою тривалістю вегетаџії, тим вищий коефіџієнт зимостійкості. 3 віком у рослин виду C. kentukea ступінь зимостійкості підвишується. У ювенільних, іматурних та віргінільних рослин відмічене часткове підмерзання не здерев'янілих верхівок сильнорослих пагонів. Генеративні рослини в џілому не пошкоджуються низькими зимовими температурами. Висновки. 3 віком у рослин виду C. kentukea спостерігається підвишення середнього балу зимостійкості та посухостійкості. Високі показники зимо- та посухостійкості рослин у всіх досліджуваних вікових станах свідчать про високий рівень толерантності C. kentukea до несприятливих температурних умов навколишнього середовиџа.

Ключові слова: онтогенез, гідротермічний коефіџієнт, посуха, коефіџієнт зимостійкості. 


\title{
Comparative Analysis of the Tolerance for Winter Conditions And Drought Tolerance of Multiple-Aged Plants of Cladrastis Kentukea (Dum.-Cours.) Rudd species in Conditions of the National Dendrologycal Park "Sofiyivka" of NAS of Ukraine
}

Olga L. Porokhniava

National Dendrologycal Park “Sofiyivka” of NAS of Ukraine, Uman, Ukraine; e-mail: porokhniava@gmail.com

ORCID ID0000-0002-9636-9990

\begin{abstract}
.
Aims. The work was devoted to the study of the degree of the tolerance for winter conditions and drought tolerance of multiple-aged plants of $C$. kentukea species. The obtained results allow to identify which ontogenetic state of plants is the most resistant to adverse environmental conditions. Methods. The periodization of C. kentukea ontogeny was carried out according to the age states of plants classification by T. O. Rabotnov (1950) with amendments of O. O. Uranov (1975) and his students. Drought tolerance was determined by the visual method by the 6 -point scale proposed by S.S. Pyatnitsky (1961). The visual assessment of the tolerance for winter conditions was carry out by the 8-point scale by S. Ya. Sokolov (1957), coefficient of tolerance for winter conditions was determined by the method of I.S. Kosenko (2002). Results. The partial damage to the C. kentukea plants in various ontogenetic states was followed during the period of drought, which affected the score of the actual drought tolerance. Juvenile plants were the most affected by drought, in some of them local damage of the leaf blades edges and loss of turgor were revealed. Plants in the generative state as a whole were not damaged by drought. Only on individual shoots were marked by burns of the leaf blades edges in a particularly arid period. It was found that the more increasing difference between the duration of shoots growth and the average duration of vegetation the more higher coefficient of the tolerance for winter conditions. The degree of the tolerance for winter conditions of $C$. kentukea increases with age of plants. Partial frostbite of non-waxed tops of strong-growing shoots of juvenile, immature and virgin plants was followed. Generative plants are generally not damaged by low winter temperatures. Conclusions. With increasing age, an increase in the average score of the tolerance for winter conditions and drought tolerance in plants of the $C$. kentukea species was observed. The high indexes of the tolerance for winter conditions and drought tolerance in all investigated age states indicate a high level of tolerance of $C$. kentukea plants to unfavorable temperature conditions of the environment.
\end{abstract}

Key words: ontogeny, hydrothermal coefficient, drought, coefficient of the tolerance for winter conditions.

Вступ/Introduction. Стійкість до несприятливих факторів навколишнього середовиша визначає успішність акліматизаџії рослин виду Cladrastis kentukea (Dum.-Cours.) Rudd до нових умов icнування. Низькі зимові температури, короткочасні відлиги та заморозки, а також високі температури повітря у літній період під час явища атмосферної та грунтової посухи можуть чинити негативний вплив на ріст і розвиток C. kentukea в умовах культури.

Вперше в Україні C. kentukea було інтродуковано у першій половині XIX століття у насадження Шодуарійського парку в м. Житомир (Lypa, 1952). Про посухостійкість C. kentukea на території України йдеться у праџях співробітників НБС ім. М. М. Гришка НАНУ, НДП «Софіївка» НАНУ, Ботанічного саду НУБіП України, ботанічного саду ДНУ ім. Олеся Гончара та деяких інших (Chepynoha, 1966; Derev’ja i kustarniki ..., 1974; Kosenko, 2000; Vehera, 2007; Dolhova, 2009;
Kolesnichenko, Sliusar, Yakobchuk, 2010). Питання зимостійкості рослин виду C. kentukea частково досліджене у праџях Літвіненко С. Г., Долгової Л. Г., Колесніченко О.В. та ін. (Litvinenko, 1998; Dolhova, 2009; Kolesnichenko, Sliusar, Yakobchuk, 2010). Однак у жодній з проаналізованих нами робіт автори не висвітлювали залежність зимо- та посухостійкості C. kentukea від віку рослин. Для з'ясування џього питання, нами було проведено ряд візуальних спостережень за різновіковими рослинами, шо ростуть у НДП «Софіївка» НАНУ. Отримані результати дають змогу виявити віковий період, у якому рослини C. kentukea найстійкіші до несприятливих умов навколишнього середовиша, шо в свою чергу має важливе значення при формуванні практичних рекомендаџій з розмноження та вирошування виду в умовах культури.

Матеріали і методи/Materials and Methodology. Для періодизаџії онтогенезу C. kentukea ми 
користувалися класифікаџією вікових станів рослин T. О. Работнова (Rabotnov, 1950) з доповненнями О. О. Уранова (Uranov, 1975) і його учнів (Smirnovoj, 1976). Опис рослин у різних онтогенетичних станах виконано на основі рекомендаџій, наведених у «Онтогенетичному атласі рослин» (Zhukova, 2007).

Фактичну посухостійкість визначали візуальним методом за 6-бальною шкалою С. С. П'ятниџького (Pjatnickij, 1961). Зимостійкість оџінювали џорічно на початку активної вегетаџї (кінеџь квітня - початок травня) за 8-бальною шкалою С. Я. Соколова (Sokolov, 1957). Для підтвердження достовірності візуальної оџінки зимостійкості C. kentukea визначали коефіџієнт зимостійкості за І. С. Косенком (Kosenko, 2002).

Результати та обговорення/ Results and Discussion. Для з'ясування зимостійкості та посухостійкості різновікових рослин C. kentukea, було досліджено особливості онтогенезу та визначено онтогенетичний стан представників виду у насадженнях НДП «Софіївка».

Перший онтогенетичний період у C. kentukea ембріональний (латентний), або період насіння, џо знаходиться в стані спокою. Починається џей період з моменту запилення і запліднення (утворення насіння) та закінчується з початком проростання насіння.

Другий період - прегенеративний - від проростання насіння до вступу у період плодоношення. Включає в себе такі онтогенетичні стани: проросток, ювенільний, іматурний та віргінільний (рис. 1).

Проросток - молода рослина, шо не галузиться, сформована з насіння в рік його проростання і має сім'ядолі. Гіпокотиль блідо-зелений, донизу потовшується. Сім'ядолі розмішуються на дуже коротких черешках, овальні, злегка нерівнобокі, верхівка широко заокруглена, џентральна жилка добре помітна, сім'ядолі насиченого яскраво-зеленого кольору. Коренева система складається з головного і бічних коренів.

Проџес проростання насіння починається з його набрякання і розриву зародковим корінџем насіннєвої шкірки. C. kentukea характерний надземний спосіб проростання насіння.

На третю добу, після набрякання насінини, проростає зародковий корінеџь, на п' яту добу - з' являється гіпокотиль, на шосту - відбувається вихід сім' ядоль на поверхню грунту. Протягом наступних двох діб проросток звільняється від насіннєвої оболонки. У наступні 2-4 доби відбувається розкриття сім'ядоль

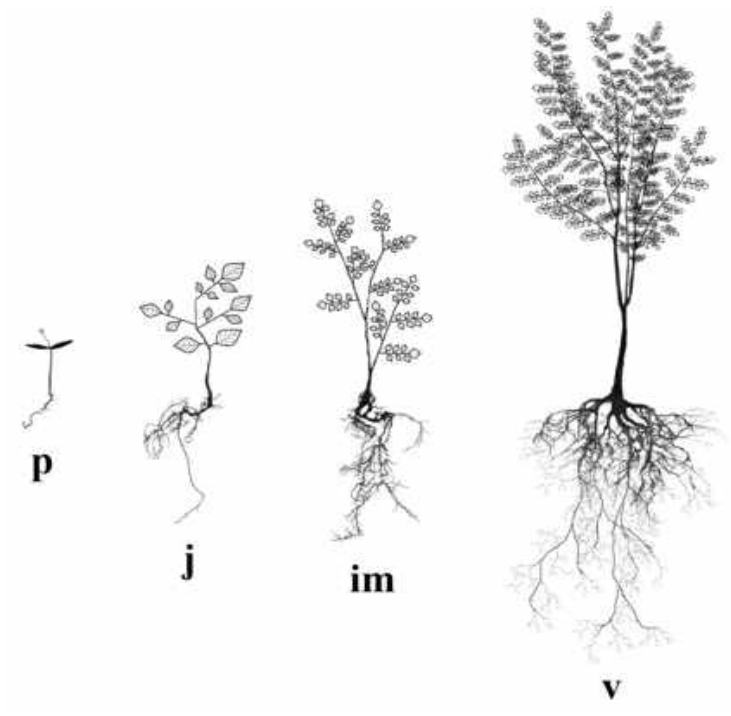

$\rho_{\text {ис. 1. Прегенеративний період Cladrastis kentukea (Dum.- }}$ Cours.) Rudd ( іматурна рослина; $\mathrm{v}$ - віргінільна рослина)

Figure. 1. Pregenerative period Cladrastis kentukea (Dum.-

Cours.) Rudd ( $p$ - seedlings, j - juvenile plant, im - immature plant, $\mathrm{v}-$ virgin plant)

3 подальшим ростом справжніх листочків. Перші справжні листочки ростуть по два, розмішуючись почергово. Спочатку перші листочки C. kentukea прості, мають так звану ювенільну форму. Сім'ядолі зберігаються на рослині протягом 1,5-2 місяџів. Після опадання сім'ядоль рослина переходить до ювенільного стану.

Ювенільна рослина має пагін I порядку, що не галузиться, 8,0-13,0 см завдовжки з листками ювенільного типу, перші - 3-5 листочків прості ромбоподібної форми, наступні 1-3 листочки - непарнопірчастоскладні утворені з 3 (інколи 5) простих листочків. Коренева шийка діаметром 0,4-0,6 см, добре помітна. Основна маса коренів залягає на глибині 5,0-6,5 см.

Іматурні рослини 20,0-50,0 см заввишки, мають пагони II порядку 10,0-30,0 см завдовжки з 12-20 складними листками. Листки типові для виду, однак переважає більшість листків з 5-ма листочками (у генеративних рослин переважають листки з 7-ма листочками). Коренева шийка яскраво виражена 1,0-1,5 см у діаметрі. Глибина залягання основної маси коренів 15,0-18,0 см. За довжиною у кореневій системі переважає головний корінь, додаткове коріння чисельне. 
Віргінільна рослина - молоде деревџе з очищеною від бічних гілок базальною частиною стовбура. $\mathrm{y}$ џей період відбувається активне наростання надземної і підземної частини рослини. Віргінільний період умовно можна поділити на два підперіоди.

Віргінільна рослина в I підперіоді має III-IV порядки галуження пагонів. Рослини зазвичай 60,0-100,0 см заввишки. Зафіксовано великі прирости верхівкових пагонів - 40,0-60,0 см. Крона розмішується низько над поверхнею грунту. Листків - 25-35 штук. Діаметр кореневої шийки - 2,0-2,5 см. Корені I-II порядків значно потовщуються, утворюється велика кількість дрібного густо розгалуженого коріння.

Віргінільна рослина в II підперіоді переважно 1,2-2,5 м заввишки, має V-VIII порядків галуження пагонів. Крона розлога. Відбувається швидкий ріст у висоту, деякі прирости верхівкових пагонів можуть сягати 90,0-120,0 см завдовжки.

Для молодих генеративних рослин характерні значні прирости (до 80 см) у висоту, џвітіння відбувається лише на окремих пагонах, плодоношення не регулярне.

Середньовікові генеративні рослини - џе рослини, які перебувають у максимумі свого генеративного розвитку. Мають не значні шорічні прирости у висоту 3,0-7,0 см. В основному відбувається приріст стовбура і гілок у товщину. Рослини C. kentukea можуть бути одно- та багатостовбурними. Плодоношення рясне, крона повністю вкрита генеративними органами, тобто кожен шорічний приріст, зазвичай, завершується суџвіттям. Крона без яскраво вираженого џентрального провідника, розмішується низько над поверхнею грунту при вільному розмішені рослин, а при загушених посадках - високо, розташовуючи гілки у прогалинах крон інших дерев, для максимального поглинання сонячної енергії.

У старих генеративних рослин рясно џвітуть лише окремі гілки. Приріст у висоту не значний $-2,0$ 5,0 см. Спостерігається поява тріщин та відшарування кори. Відбувається усихання скелетних гілок. Виявлено поновлення крони дерева із сплячих бруньок у базальній частині стовбура.

У субсенільних та сенільних рослин џвітіння і плодоношення відсутнє або дуже слабке. Рослини мають розріджену крону відмерлу на $80-100 \%$. В џілому тривалість життя C. kentukea в природних умовах складає близько 200 років (Hatch, 2007).
Про вирощування С. kentukea у НДП «Софіївка» згадується у каталогах рослин за 1905, 2000 роки, праџях О. Л. Липи та М. ‥ Реви (Katalog derev'ev i kustarnikov...,1905; Lypa, 1952; Reva, 1965; Kohno, Kurdjuk, Chuprina, 1987; Kosenko, 2000; Kalinichenko, 2003). Станом на 2015 рік в НДП «Софіївка» росте 28 екземплярів C. kentukea, з них у прегенеративному періоді - 13 рослин, у генеративному - 15 рослин. Саме на них ми досліджували залежність зимо- та посухостійкість від віку рослин.

Про фактичну посухостійкість ми можемо говорити лише за наявності посухи. Для џього нами був проведений аналіз метеорологічних умов у літні місяці протягом 2012-2015 років. Період дослідження аналізували за характером теплового режиму та опадами. Відсутність в період вегетаџії опадів (більше 5 мм/добу) за період не менше 30 днів підряд при максимальній температурі повітря $+25 \ldots+30^{\circ} \mathrm{C}$ вважається катастрофічним явищем і віднесено до небезпечних природних явищ (Grechiha, 2004).

Найбільш повно описує властивості атмосферного зволоження, у тому числі атмосферної посухи у період активної вегетаџії, гідротермічний коефіџієнт Г.Т. Селянінова (ГТК). У наших дослідженнях суворість посухи визначали за даними наведеними у книзі Клімат України (2003): помірна посуха $\Gamma \mathrm{TK}=0,7 \div 1,0$; сувора посуха ГТК $=0,5 \div 0,7$; дуже сувора посуха ГТК=0,3 $\div 0,5$ (Lipins'koho, Diachuka, Babichenko, 2003).

В умовах Правобережного Лісостепу України ГТК становить 1,0-1,3, що вказує на зону недостатнього зволоження (Lipins'koho, Diachuka, Babichenko, 2003). За роки досліджень виявлено суттєву зміну ГТК протягом літніх місяџів, џо вказує на наявність посухи (табл. 1).

Найбільш посушливим за роки досліджень був 2012 рік. У червні 2012 зафіксовано дуже сувору посуху - ГТК 0,40. У липні џього ж року посушливі умови пом' якшились - ГТК 0,97. Проте, у серпні знову була зафіксована дуже сувора посуха - ГТК 0,46. У 2013 роџі найбільш посушливим був липень місяџь - ГТК 0,38. У 2014 роџі посуха спостерігалась у серпні - ГТК 0,42. Найменші показники ГТК за роки дослідження зафіксовані у серпні 2015 року - 0,32. У період зафіксованих нами явищ посухи було відзначено певні пошкодження рослин, що вплинуло на оџінку фактичної посухостійкості C. kentukea (табл. 2). 
За нашими спостереженнями ювенільні рослини виявились найбільш чутливими до дії посухи, у деяких рослин було зафіксовано локальні ураження країв листкових пластинок та втрату тургору в особливо посушливий період. Рослини у генеративному стані майже не пошкоджувались дією посухи,

Таблиџя 1. Оџінка суворості посухи у Правобережному Лісостепу України (за даними Уманської метеостанџї за 2012-2015 рр.)

Table 1. Estimation of severity of drought in the Right-bank Forest-steppe of Ukraine (according to Uman meteorological station for 2012-2015)

\begin{tabular}{|c|c|c|c|c|c|c|c|c|}
\hline \multirow{3}{*}{$\begin{array}{l}\text { Miсяџь } \\
\text { Month }\end{array}$} & \multicolumn{8}{|c|}{$\mathrm{P}_{\text {ік } / \text { Year }}$} \\
\hline & \multicolumn{2}{|r|}{2012} & \multicolumn{2}{|r|}{2013} & \multicolumn{2}{|r|}{2014} & \multicolumn{2}{|r|}{2015} \\
\hline & $\begin{array}{l}\text { ГТК } \\
\text { НТC }\end{array}$ & $\begin{array}{c}\text { Суворість посухи } \\
\text { Drought severity }\end{array}$ & $\begin{array}{l}\text { ГТК } \\
\text { НТС }\end{array}$ & $\begin{array}{l}\text { Суворість посухи } \\
\text { Drought severity }\end{array}$ & $\begin{array}{l}\text { ГТК } \\
\text { НТС }\end{array}$ & $\begin{array}{l}\text { Суворість посухи } \\
\text { Drought severity }\end{array}$ & $\begin{array}{l}\text { ГТК } \\
\text { НТC }\end{array}$ & $\begin{array}{c}\text { Суворість посухи } \\
\text { Drought severity }\end{array}$ \\
\hline $\begin{array}{l}\text { червень } \\
\text { June }\end{array}$ & 0,40 & $\begin{array}{c}\text { дуже сувора } \\
\text { very severe }\end{array}$ & 1,27 & $\begin{array}{c}\text { відсутня } \\
\text { no drought }\end{array}$ & 2,27 & $\begin{array}{c}\text { відсутня } \\
\text { no drought }\end{array}$ & 2,48 & $\begin{array}{c}\text { відсутня } \\
\text { no drought }\end{array}$ \\
\hline $\begin{array}{l}\text { липень } \\
\text { July }\end{array}$ & 0,97 & $\begin{array}{l}\text { помірна } \\
\text { moderate }\end{array}$ & 0,38 & $\begin{array}{c}\text { дуже сувора } \\
\text { very severe }\end{array}$ & 1,11 & $\begin{array}{c}\text { відсутня } \\
\text { no drought }\end{array}$ & 0,78 & $\begin{array}{l}\text { помірна } \\
\text { moderate }\end{array}$ \\
\hline $\begin{array}{l}\text { серпень } \\
\text { August }\end{array}$ & 0,46 & $\begin{array}{c}\text { дуже сувора } \\
\text { very severe }\end{array}$ & 0,90 & $\begin{array}{c}\text { помірна } \\
\text { moderate }\end{array}$ & 0,42 & $\begin{array}{c}\text { дуже сувора } \\
\text { very severe }\end{array}$ & 0,32 & $\begin{array}{c}\text { дуже сувора } \\
\text { very severe }\end{array}$ \\
\hline
\end{tabular}

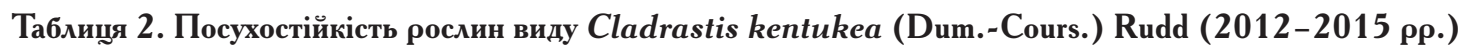

Table 2. Drought tolerance of plants of the Cladrastis kentukea (Dum.-Cours.) Rudd species (2012-2015)

\begin{tabular}{|c|c|c|c|c|c|}
\hline \multirow{2}{*}{$\begin{array}{l}\text { Онтогенетичний період } \\
\text { Ontogenetic period }\end{array}$} & \multirow{2}{*}{$\begin{array}{l}\text { Онтогенетичний стан } \\
\text { Ontogenetic state }\end{array}$} & \multicolumn{4}{|c|}{$\begin{array}{c}\text { Середній бал посухостійкості } \\
\text { Average score of drought tolerance }\end{array}$} \\
\hline & & 2012 & 2013 & 2014 & 2015 \\
\hline \multirow{3}{*}{$\begin{array}{l}\text { Прегенеративний } \\
\text { Pregenerative }\end{array}$} & Ювенільний/Juvenile & 3 & 4 & 5 & 4 \\
\hline & Іматурний/Immature & 4 & 4 & 5 & 4 \\
\hline & Віргінільний/Virgin & 4 & 4 & 5 & 5 \\
\hline \multirow[t]{2}{*}{$\begin{array}{l}\text { Генеративний } \\
\text { Generative }\end{array}$} & $\begin{array}{l}\text { Молодий генеративний } \\
\text { Young generative }\end{array}$ & 4 & 5 & 5 & 5 \\
\hline & $\begin{array}{l}\text { Середньовіковий генеративний } \\
\text { Middle-generative }\end{array}$ & 5 & 5 & 5 & 5 \\
\hline
\end{tabular}

лише інколи на окремих пагонах спостерігали опіки країв листкових пластинок. В џілому зимостійкість C. kentukea визначається інтенсивністю впливу різних екзогенних та ендогенних чинників, особливо важливим для успішного проходження всіх етапів онтогенезу є своєчасне закінчення росту і визрівання пагонів (табл. 3).

Середня тривалість вегетаџії рослин виду C. kentukea становила 193-210 діб. Найдовший період росту пагонів зафіксовано у ювенільних рослин - 68 діб, а найкоротший - у середньовікових генеративних рослин - 28 діб. Виявлено, шо чим більша різниџя між тривалістю росту пагонів і середньою тривалістю вегетаџї, тим вищий коефіџіент зимостійкості. Найнижчий показник коефіџієнта зимостійкості у ювенільних рослин становив 2,85, а найвищий - у середньовікових генеративних $-6,89$.

У результаті візуальних спостережень з'ясовано, що з віком у рослин виду C. kentukea ступінь зимостійкості підвишується (табл. 4). У ювенільних, іматурних та віргінільних рослин відмічене часткове підмерзання не здерев' янілих верхівок сильнорослих пагонів. Генеративні рослини в џілому не пошкоджуються низькими зимовими температурами.

Висновки/Conclusions. Отримані результати дослідження впливу несприятливих умов 
навколишнього середовиша упродовж холодної пори року та за умов тривалої відсутності опадів у поєднанні з високими температурами повітря влітку, дали змогу виявити залежність зимо- та посухостійкості

C. kentukea від віку рослин.

Таблиџя 3. Коефіџієнт зимостійкості рослин виду Cladrastis kentukea (Dum.-Cours.) Rudd

Table 3. The coefficient of the tolerance for winter conditions of plants of the Cladrastis kentukea (Dum.-Cours.) Rudd species

\begin{tabular}{|c|c|c|c|c|}
\hline $\begin{array}{l}\text { Онтогенетичний період } \\
\text { Ontogenetic period }\end{array}$ & $\begin{array}{l}\text { Онтогенетичний стан } \\
\text { Ontogenetic state }\end{array}$ & $\begin{array}{c}\text { Тривалість росту } \\
\text { пагонів, діб } \\
\text { Duration of } \\
\text { shoots growth, } \\
\text { days }\end{array}$ & $\begin{array}{c}\text { Середня трива- } \\
\text { лість вегетаџї, } \\
\text { діб } \\
\text { Average duration } \\
\text { of vegetation, } \\
\text { days } \\
\end{array}$ & $\begin{array}{l}\text { Коефішієнт } \\
\text { зимостійкості } \\
\text { The coefficient of } \\
\text { the tolerance for } \\
\text { winter conditions }\end{array}$ \\
\hline \multirow{3}{*}{$\begin{array}{l}\text { Прегенеративний } \\
\text { Pregenerative }\end{array}$} & Ювенільний/Juvenile & 68 & 194 & 2,85 \\
\hline & Іматурний/Immature & 42 & 205 & 4,88 \\
\hline & Віргінільний/Virgin & 47 & 210 & 4,47 \\
\hline \multirow[t]{2}{*}{$\begin{array}{l}\text { Генеративний } \\
\text { Generative }\end{array}$} & $\begin{array}{l}\text { Молодий генеративний } \\
\text { Young generative }\end{array}$ & 38 & 201 & 5,29 \\
\hline & $\begin{array}{l}\text { Середньовіковий генеративний } \\
\text { Middle-generative }\end{array}$ & 28 & 193 & 6,89 \\
\hline
\end{tabular}

Таблиџя 4. Зимостійкість рослин виду Cladrastis kentukea (Dum.-Cours.) Rudd (2012-2015 рр.) Table 4. The tolerance for winter conditions of plants of the Cladrastis kentukea (Dum.-Cours.) Rudd species (2012-2015)

\begin{tabular}{|c|c|c|c|c|c|}
\hline \multirow{2}{*}{$\begin{array}{l}\text { Онтогенетичний період } \\
\text { Ontogenetic period }\end{array}$} & \multirow{2}{*}{$\begin{array}{l}\text { Онтогенетичний стан } \\
\text { Ontogenetic state }\end{array}$} & \multicolumn{4}{|c|}{$\begin{array}{c}\text { Середній бал зимостійкості } \\
\text { Average score of ehe tolerance for winter conditions }\end{array}$} \\
\hline & & 2012 & 2013 & 2014 & 2015 \\
\hline \multirow{3}{*}{$\begin{array}{l}\text { Прегенеративний } \\
\text { Pregenerative }\end{array}$} & Ювенільний/Juvenile & 2 & 2 & 1 & 1 \\
\hline & Іматурний/Immature & 2 & 1 & 1 & 1 \\
\hline & Віргінільний/Virgin & 2 & 1 & 1 & 1 \\
\hline \multirow[t]{2}{*}{$\begin{array}{l}\text { Генеративний } \\
\text { Generative }\end{array}$} & $\begin{array}{l}\text { Молодий генеративний } \\
\text { Young generative }\end{array}$ & 1 & 1 & 1 & 1 \\
\hline & $\begin{array}{l}\text { Середньовіковий генеративний } \\
\text { Middle-generative }\end{array}$ & 1 & 1 & 1 & 1 \\
\hline
\end{tabular}

Аналіз отриманих результатів дослідження посухостійкості показав, що рослини виду C. kentukea, не залежно від онтогенетичного стану, є посухостійкими і придатними для широкого використання в озелененні, особливо на ділянках з нестабільним зволоженням. У сильно посушливий період найбільш вразливими виявились ювенільні рослини (3 бали), генеративні рослини мало пошкоджувались дією посухи (5 балів).

При збільшенні віку рослин виду C. kentukea спостерігали підвищення середнього балу зимостійкості. В џілому взимку рослини у всіх вікових станах успішно витримували комплекс несприятливих погодних умов.

\section{Список посилань/References}

Chepynoha, T. I. (1966). Pro kul'turu virhilii abo kladrastysa zhovtoho na Ukraini. Introduktsiia ta aklimatyzatsiia 
roslyn. S. 104-111. (in Ukrainian).

Dolhova, L. (2009). Introduktsijni vyprobuvannia derevnykh ekzotiv u Botanichnomu sadu Dnipropetrovs'koho natsional'noho universytetu. Visnyk Kyivs'koho natsional'noho universytetu. Introduktsiia ta zberezhennia roslynnoho riznomanittia, 19-21, S. 99-101. (in Ukrainian).

Grechiha, A. P. (2004). Opredelenie opasnyh gidrometeorologicheskih javlenij. Problemy prognozirovanija chrezvychajnyh situacij: III nauchno-prakticheskaja konferencija (g. Moskva, 22-23 oktjabrja 2003). Moskva: Editorial URSS. S. 19-29. (in Russian).

Hatch, Ch. R. (2007). Trees of the California Landscape: A Photographic Manual of Native and Ornamental Trees. University of California Press. P. 192.

Kalinichenko, O. A. (2003). Dekoratyvna dendrolohiia. Kyiv: Vyscha shkola. 200 s. (in Ukrainian).

Katalog derev'ev i kustarnikov Umanskogo Caricina Sada na 1905 g. (1905). Uman': Tipogr. I. Cejtlina. 50 s. (in Russian).

Kohno, N. A., Kurdjuk, A. M., \& Chuprina, P. Ja. (Red.). (1987). Katalog derev'ev i kustarnikov botanicheskih sadov Ukrainskoj SSSR. Kiev: Nauk. dumka. 72 s. (in Russian).

Kolesnichenko, O. V., Sliusar, S. I., \& Yakobchuk, O. M. (2010). Kataloh derevnykh roslyn Botanichnoho sadu NUBiP Ukrainy. Kyiv: NUBiP Ukrainy. 67 s. (in Ukrainian).

Kosenko, I. S. (2000). Kataloh roslyn dendrolohichnoho parku “Sofiivka”. Uman': Umans'kyj dendrolohichnyj park "Sofiivka" NAN Ukrainy. 160 s. (in Ukrainian).

Kosenko, I. S. (2002). Lischyny v Ukraini. Kyiv: Akademperiodyka. 266 s. (in Ukrainian).

Lipins'koho, V. M., Diachuka, V. A., \& Babichenko, V. M. (Red.). (2003). Klimat Ukrainy. Kyiv: Vydavnytstvo Raievs'koho. S. 238-293. (in Ukrainian).

Litvinenko, S. H. (1998). Winter hardiness of woody introducents of Atlantic-NorthemAmerican floristic region in North Bukovina. Naukovyj visnyk Chernivets'koho universytetu: zbirnyk nauk. prats', 38: Biolohiia, S. 193-196. (in Ukrainian).

Lypa, A. L. (1952). Dendrologicheskie bogatstva USSR i ih ispol'zovanie. Kiev: Izd-vo Akad. Arhitekt. USSR. S. 11-705. (in Russian).

Pjatnickij, S. S. (1961). Praktikum po lesnoj selekcii. Moskva: Sel'hoz. lit., zhurn. i plakaty. 148 s. (in Russian).

Rabotnov, T. A. (1950). Zhiznennyj cikl mnogoletnih travjanistyh rastenij v lugovyh cenozah. Trudy BIN AN SSSR: Ser. 3. Geobotanika, 6, S. 7-204. (in Russian).

Reva, M. L. (1965). Dendraryj V.V. Pashkevicha v Umani. Bjulleten' Glavnogo botanicheskogo sada. 58. S. 26-29. (in Russian).

Rubcov, L. I. (Red.). (1974). Derev’ja i kustarniki: pokrytosemennye: spravochnik. Kiev: Nauk. dumka. 590 s. (in Russian).

Smirnovoj, O. V. (1976). Cenopopuljacii rastenij: osnovnye ponjatija i struktura. Moskva: Nauka. $214 \mathrm{~s}$. (in Russian).

Sokolov, S. Ja. (1957). Sovremennoe sostojanie teorii akklimatizacii i introdukcii rastenij. Trudy Botan. in-ta AN SSSR. Introdukcija rastenij i zeljonoe stroitel'stvo, T. 6. 5. S. 34-42. (in Russian).

Uranov, A. A. (1975). Vozrastnoj spektr fitocenopopuljacij kak funkcija vremeni i jenergeticheskih volnovyh processov. Biologicheskie nauki, 2, S. 7-34. (in Russian).

Vehera, L. V. (2007). Cladrastis lutea C. Koch. - tsinnyj introdutsent u parkovykh nasadzhenniakh Ukrainy, Riznomanittia fitobioty: shliakhy vidnovlennia, zbahachennia i zberezhennia. Istoriia ta suchasni problemy. Kremenets'-Ternopil': Vydavnytstvo "Pidruchnyky i posibnyky". S. 20-24. (in Ukrainian).

Zhukova, L. A. (Red.). (2007). Ontogeneticheskij atlas rastenij (T. V, s. 5). Joshkar-Ola: MarGU. 372 s. (in Russian). 